\title{
Penurunan Ompalitis pada Bayi dengan Prosedur Memandikan dan Perawatan Tali Pusat
}

\author{
Indaryani $^{1}$, Supiyah ${ }^{2}$, Surya Dharma ${ }^{3}$ \\ ${ }^{1}$ Sekolah Tinggi Ilmu Kesehatan Sapta Bakti, Jl. Mahakam Raya, Bengkulu, 38225, Indonesia \\ ${ }^{2}$ Poltekes Kemenkes Padang, J1. Simpang Pondok Kopi Nanggalo, Padang, 25146, Indonesia \\ ${ }^{3}$ Fakultas Farmasi Universitas Andalas, Kamus Limau Manis, Padang, 25163, Indonesia \\ Indrayani101182@gmail.com \\ * corresponding author \\ Tanggal Submisi: 26 Desember 2020, Tanggal Penerimaan: 20 Februari 2021
}

\begin{abstract}
Abstrak
Infeksi tali pusat (ompalitis) adalah infeksi paling umum pada tali pusat bayi. Mandi dan perawatan tali pusat bayi sesuai dengan Prosedur Operasi Standar (SOP) adalah salah satu cara untuk mencegah ompalitis. Tujuan dari penelitian ini adalah mengetahui pengaruh penerapan standar mandi dan perawatan tali pusat dengan insiden ompalitis pada bayi. Metode penelitian kuasi eksperimental. Pengambilan sampel dengan teknik accidental sampling. Data dianalisis menggunakan uji Mann Whitney. Hasil penelitian menunjukkan penerapan standar mandi dan perawatan tali pusat berpengaruh signifikan terhadap kejadian ompalitis $(\mathrm{p}=0,03)$.
\end{abstract}

Kata kunci: ompalitis, bayi, perawatan tali pusat.

\section{Reduction of Ompalitis in Babies with Bathing and Cord Care Procedures}

\begin{abstract}
Umbilical cord infection (ompalitis) is the most common infection of the baby's umbilical cord. Bathing and caring for the baby's umbilical cord in accordance with Standard Operating Procedures (SOP) is one way to prevent ompalitis. The purpose of this study was to determine the effect of applying bath standards and cord care with the incidence of ompalitis in infants. Quasi-experimental research method. Sampling with accidental sampling technique. Data were analyzed using the Mann Whitney test. The results showed that the application of bath standards and umbilical cord care had a significant effect on the incidence of ompalitis ( $p=0.03)$.
\end{abstract}

Keywords: ompalitis, bathing, cord care. 


\section{PENDAHULUAN}

Saat lahir tali pusat dipotong dan akan terpapar lingkungan sekitar. Struktur ini rentan terinfeksi lokal (omphalitis) dan jika tidak dikenali dan ditangani sedini mungkin dapat berkembang menjadi infeksi sistemik dan gangguan multi organ bahkan kematian. Perawatan tali pusat penting untuk mencegah infeksi pada bayi baru lahir Purnamasari, L. (2016).

Infeksi tali pusat telah menjadi penyebab kesakitan dan kematian secara terus menerus di berbagai negara. setiap tahunya 500.017 bayi meninggal karena tetanus neonatorum dan 460.017 meninggal akibat infeksi bakteri (Sodikin, 2015). Dari 4 juta kematian bayi pertahun diseluruh dunia, 99\% terjadi di Negara berkembang dan hampir setengah bayi meninggal disebabkan oleh infeksi. Infeksi pada bayi bisa karena paparan tali pusat terhadap pathogen invasif yang menyebabkan terjadinya ompalitis sehingga mengalami komplikasi menjadi tetanus neonatorum dan sepsis. WHO juga melaporkan bahwa 460.000 kematian pada neonatal setiap tahunnya terjadi dinegara berkembang diawali oleh ompalitis (Alam, 2008; Erenel, 2010).

Secara Nasional kejadian/insidensi infeksi neonatal belum dilaporkan secara rinci. Tetapi laporan angka kejadian di Rumah Sakit menunjukkan jauh lebih tinggi khususnya bila Rumah Sakit tersebut merupakan tempat rujukan. Seperti di RS Cipto Mangunkusumo, angka kejadian infeksi neonatal mencapai 13,7\% dan angka kematian mencapai 14\% (Kosim, 2010). Profil kesehatan juga tidak melaporkan data morbiditas dan mortalitas bayi karena infeksi, tetapi hanya didapatkan jumlah kematian bayi di Provinsi Sumatra Barat 10,7\% dari jumlah kelahiran hidup dan 9,7\% dari jumlah kematian bayi terdapat di kabupaten X yang merupakan porsentase tertinggi dari $19 \mathrm{Kab} /$ Kota di Provinsi Sumatra Barat Tahun 2012. Sementara menurut hasil pengkajian residensi peneliti pada bulan November 2013 di RSUD M yang merupakan RS rujukan di Kabupaten X didapatkan data dari 766 bayi yang dirawat tali pusatnya terdapat $133(17,36 \%)$ yang mengalami infeksi tali pusat (Profil Kesehatan Provinsi Sumatra Barat, 2012; Data SPM RSUD M periode Januari-Juli 2013). Oleh karena itu harus dilakukan upaya untuk mencegah infeksi yang dapat menyebabkan kematian pada bayi.

Perawatan tali pusat yang baik dan benar akan menimbulkan dampak positif yaitu tali pusat akan puput pada hari ke-5 dan hari ke- 7 tanpa ada komplikasi, sedangkan dampak negatif dari perawatan tali pusat yang tidak benar adalah bayi akan mengalami penyakit tetanus neonatorum (Depkes RI, 2015). Upaya pencegahan infeksi tali pusat dan tetanus neonatorum adalah perawatan tali pusat. Perawatan tali pusat adalah tindakan perawatan yang bertujuan untuk merawat tali pusat bayi baru lahir agar tetap kering (Yuspita, 2017). Perawatan tali pusat yang baik seperti menghindari penggunaan bedak dermatol, dan penggunaan ramuan tradisional yang kurang memperhatikan kesterilannya sangat penting (Depkes RI, 2016)

Subyek yang rentan mengalami infeksi nosokomial salah satunya adalah bayi. Perawatan tali pusat adalah bagian dari perawatan bayi yang merupakan

Indaryani, et.al (Penurunan Ompalitis pada Bayi dengan Prosedur Memandikan....) 
faktor yang paling mempengaruhi terjadinya ompalitis. Menurut Jaringan Nasional Pelatihan Klinik-Kesehatan Reproduksi dalam Yefri (2010), dalam melakukan perawatan bayi salah satunya adalah upaya pencegahan infeksi dengan cara melakukan tindakan sesuai dengan standar, seperti mencuci tangan sebelum dan sesudah bersentuhan dengan bayi, memakai sarung tangan bersih saat menangani bayi yang belum dimandikan, semua peralatan dan perlengkapan yang akan digunakan dalam keadaan steril, khusus untuk bola karet penghisap lender jangan dipakai untuk lebih dari satu bayi, handuk, pakaian atau kain yang akan digunakan dalam keadaan bersih. Oleh karena itu semua tenaga keperawatan harus melakukan tindakan perawatan berdasarkan standar.

Berdasarkan studi pendahuluan pada tanggal 15 April 2014 di RSUD M pada tahun 2013 didapatkan data bahwa dari 10 penyakit terbanyak diruang rawat inap adalah infeksi pada nenatus yaitu $708(17,63 \%)$ kasus, dan kejadian ompalitis diruang rawat inap kebidanan $220(16,64 \%)$ kasus dari seluruh bayi yang dirawat diruang kebidanan yaitu 1322 orang. Pada bulan Maret 2014 dari 90 bayi yang dirawat terdapat 18 (20\%) bayi terjadi ompalitis. Berdasarkan wawancara kepada kepala ruangan dan wakil kepala ruangan kebidanan, sudah berbagai cara dilakukan untuk menurunkan angka kejadian ompalitis, seperti membuat kran air tersendiri untuk memandikan bayi, mengganti tenaga yang memandikan dan merawat tali pusat bayi dengan tenaga perawat ruangan sampai bayi pulang yang semula hanya mandi pertama saja selanjutnya dimandikan oleh keluarga bayi mulai pada tahun 2014. Perawatan bayi khususnya memandikan dan perawatan tali pusat dapat mencegah terjadinya infeksi terutama ompalitis bila dilakukan dengan standar yang benar. Fenomena yang terjadi di RSUD M angka kejadian ompalitis pada bayi masih jauh dari target standar pelayanan minimal (SPM) Kemenkes No.29 Tahun 2008 ( $\leq 1,5 \%$ ) yaitu 16,64 \% pada tahun 2013 dan $20 \%$ pada bulan Maret 2014, namun tidak ada evaluasi dari manajemen tentang pelaksanaan standar memandikan dan perawatan tali pusat bayi yang dilakukan oleh tenaga pelaksana tindakan keperawatan. Jika masalah ini dibiarkan terus menerus, maka angka kesakitan bahkan kematian pada bayi juga menjadi tinggi.

\section{METODE}

Penelitian ini adalah penelitian kuantitatif quasi eksperiement dengan desain penelitian One Group Pre test-Post test Design. Penelitian kuantitatif adalah penelitian yang datanya berbentuk angka atau data kualitatif yang diangkakan. Quasi eksperiement adalah penelitian yang mengujicoba suatu intervensi pada sekelompok subjek dengan atau tanpa kelompok kontrol namun tidak dilakukan randomisasi untuk memasukan subjek kedalam kelompok perlakuan atau kelompok kontrol. (Sopiyadun, 2011; Sastroasmoro, 2011; Dharma, 2011).

Populasi dalam penelitian ini adalah jumlah bayi yang dirawat per bulan. Populasi ini dihitung dari bayi yang dirawat bulan Januari-Maret 2014 yaitu 229 orang dengan rata-rata 76 orang/bulan. Populasi adalah keseluruhan dari unit didalam pengamatan yang akan dilakukan. Populasi juga merupakan wilayah 
generalisasi yang terdiri dari obyek, subyek yang mempunyai kualitas dan karakteristik tertentu yang ditetapkan oleh peneliti untuk dipelajari dan kemudian ditarik kesimpulannya (Sastroasmoro, 2011).

Pada penelitian ini sampel diambil sebesar $20 \%$ dari populasi. Berdasarkan hasil perhitungan, maka sampel yang digunakan dalam penelitian ini adalah 32 orang Perhitungan besar sampel dapat diambil berdasarkan pada persentase dari besarnya populasi yaitu sampel sebesar 5\%, 10\%, atau 20\%, (Saryono dan Anggraini, 2013). Teknik sampling yang digunakan dalam pengambilan sampel pada penelitian ini adalah non probability sampling dengan accidental sampling. Teknik accidental sampling adalah Teknik pengumpulan data dari subyek yang ditemuinya selama dilakukan penelitian (Nursalam, 2011; Sugiyono, 2013; Saryono, 2013).

\section{HASIL DAN PEMBAHASAN}

Diperoleh dari hasil pengumpulan data disajikan dalam bentuk tabel distribusi frekuensi, ukuran tendensi sentral atau grafik (Saryono dan Anggraini, 2013). Analisa bivariat adalah analisa yang dilakukan pada dua variabel yang diduga hubungannya atau memiliki korelasi, dan analisa ini dilakukan untuk mengetahui hubungan antar variabel. Analisa bivariat merupakan analisis untuk mengetahui interaksi dua variabel, baik berupa komparatif, asosiatif maupun korelatif. Analisa bivariat digunakan untuk mengetahui apakah ada hubungan atau pengaruh antara dua atau lebih variabel dan untuk mengetahui apakah ada perbedaan antara dua atau lebih variabel (Hastono \& Sabri, 2010; Notoadmojo, 2010; Dharma, 2011).

\section{Gambaran Karakteritik Responden}

Tabel 1. Distribusi frekuensi karakteristik bayi

Pelaksanaan

Standar

\begin{tabular}{|c|c|c|c|c|c|c|c|c|c|c|c|c|c|c|}
\hline \multirow[t]{2}{*}{ Variabel } & \multicolumn{6}{|c|}{$\begin{array}{c}\text { Sebelum penerapan } \\
\text { SOP }\end{array}$} & \multicolumn{6}{|c|}{ Setelah penerapan SOP } & \multicolumn{2}{|r|}{ Total } \\
\hline & \multicolumn{2}{|c|}{ Ompalitis } & \multicolumn{2}{|c|}{ Tdk Ompalitis } & \multicolumn{2}{|c|}{ Jumlah } & \multicolumn{4}{|c|}{ Ompalitis Tdk Ompalitis } & \multicolumn{2}{|c|}{ Jumlah } & & \\
\hline & $\mathbf{F}$ & $\%$ & $\mathbf{F}$ & $\%$ & $\mathbf{n}$ & $\%$ & I & $\%$ & $\mathbf{f}$ & $\%$ & $\mathbf{n}$ & $\%$ & & N\% \\
\hline Jns Kelamin & & & & & & & & & & & & & & \\
\hline Laki-laki & 4 & 21.1 & 5 & 26.3 & 9 & 47.4 & 1 & 5.3 & 9 & 47.4 & 10 & 52.6 & 19 & 100 \\
\hline $\begin{array}{l}\text { Perempuan } \\
\text { Cara Lahir }\end{array}$ & 2 & 15.4 & 5 & 38.5 & 7 & 53.8 & 0 & 0.0 & 6 & 46.2 & 6 & 46.2 & 13 & 100 \\
\hline $\mathrm{SC}$ & 2 & 50.0 & 0 & 0.0 & 2 & 50.0 & 0 & 0.0 & 2 & 50.0 & 2 & 50.0 & 4 & 100 \\
\hline $\begin{array}{l}\text { Spontan } \\
\text { Tmpt Lahir }\end{array}$ & 4 & 14.3 & 10 & 35.7 & 14 & 50.0 & 1 & 3.6 & 13 & 46.4 & 14 & 50.0 & 28 & 100 \\
\hline Dukun & 0 & 0.0 & 0 & 0.0 & 0 & 0.0 & 1 & 100.0 & 0 & 0.0 & 1 & 100.0 & 1 & 100 \\
\hline Rumah Sakit & 6 & 19.4 & 10 & 32.3 & 16 & 51.6 & 0 & 0.0 & 15 & 48.4 & 15 & 48.4 & 31 & 100 \\
\hline
\end{tabular}

Indaryani, et.al (Penurunan Ompalitis pada Bayi dengan Prosedur Memandikan....)

Copyright (C) 2021, Jurnal Kebidanan dan Keperawatan Aisyiyah

ISSN 1858-0610 (Print) | ISSN 2477-8184 (Online) 
Tabel 1 menunjukkan bahwa $(21,05 \%)$ bayi yang terjadi ompalitis adalah berjenis kelamin laki-laki dan terjadi pada saat dimandikan dan dirawat tali pusatnya sebelum penerapan SOP, (50\%) bayi yang terjadi ompalitis adalah yang lahir dengan SC dan terjadi pada saat dimandikan dan dirawat tali pusatnya sebelum penerapan SOP, (100\%) bayi yang terjadi ompalitis adalah yang lahir dengan dukun dan terjadi saat dimandikan dan dirawat tali pusatnya setelah penerapan SOP.

\section{Gambaran Pelaksanaan SOP Memandikan dan Perawatan Tali Pusat pada Bayi}

Tabel 2. Distribusi frekuensi pelaksanaan memandikan dan perawatan tali pusat pada bayi Sebelum penerapan SOP

Setelah penerapan SOP

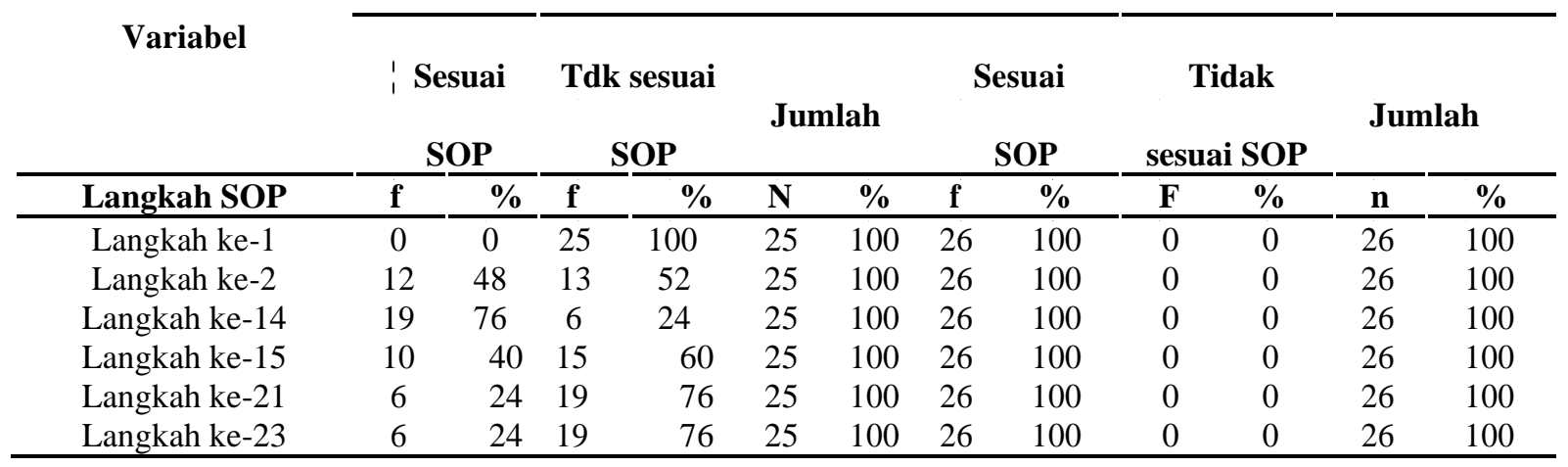

Tabel 2 menunjukkan bahwa sebelum penerapan SOP, langkah ke-1 dalam SOP (100\%) tidak dilakukan, langkah ke-2 (52\%) tidak dilakukan, langkah ke-14 dalam SOP (24\%) tidak dilakukan sesuai SOP, langkah ke-15 dalam SOP (60\%) tidak dilakukan sesuai SOP, langkah ke-21 dalam SOP (76\%) tidak dilakukan sesuai SOP dan langkah ke-23 dalam SOP (76\%) tidak dilakukan sesuai SOP. Setelah penerapan SOP semua langkah dilakukan sesuai SOP. Langkah-langkah dalam SOP yang tidak digambarkan dalam tabel, semua dilakukan (100\%) sesuai SOP.

\section{Gambaran Kejadian Ompalitis pada Bayi}

Tabel 3. Distribusi frekuensi kejadian ompalitis pada bayi

Pelaksanaan Standar

Total

\begin{tabular}{|c|c|c|c|c|c|c|}
\hline \multirow{3}{*}{ Variabel } & \multicolumn{4}{|c|}{ relaksandan stanuá } & \multicolumn{2}{|c|}{ 100ad } \\
\hline & \multicolumn{2}{|c|}{$\begin{array}{c}\text { Sebelum penerapan } \\
\text { SOP }\end{array}$} & \multicolumn{2}{|c|}{$\begin{array}{c}\text { Setelah penerapan } \\
\text { SOP }\end{array}$} & \multirow[b]{2}{*}{$\mathbf{N}$} & \multirow[b]{2}{*}{$\%$} \\
\hline & $\mathbf{F}$ & $\%$ & $\mathbf{F}$ & $\%$ & & \\
\hline \multicolumn{7}{|c|}{ Kejadian Ompalitis } \\
\hline Ompalitis & 6 & 37,5 & 1 & 6,25 & 7 & 21,88 \\
\hline Tidak Ompalitis & 10 & 62,5 & 15 & 93,75 & 25 & 78,12 \\
\hline Total & 16 & 50 & 16 & 50 & 32 & 100 \\
\hline
\end{tabular}

Indaryani, et.al (Penurunan Ompalitis pada Bayi dengan Prosedur Memandikan....) 
Tabel 3 menunjukkan bahwa $(37,5 \%)$ terjadi ompalitis pada bayi yang dimandikan dan dirawat tali pusatnya sebelum penerapan SOP dan $(6,25 \%)$ terjadi ompalitis pada bayi yang dimandikan dan dirawat tali pusatnya setelah penerapan SOP.

\section{Perbedaan Kejadian Ompalitis Pada Bayi}

Tabel 4. Perbedaan kejadian ompalitis pada bayi

\begin{tabular}{|c|c|c|c|c|c|c|c|}
\hline \multirow{3}{*}{ Variabel } & \multicolumn{5}{|c|}{ Pelaksanaan Standar } & & \multirow[t]{3}{*}{ P Velue } \\
\hline & \multicolumn{2}{|c|}{ Sblm penerapan SOP } & \multicolumn{2}{|c|}{ Stlh penerapan SOP } & \multicolumn{2}{|c|}{ Total } & \\
\hline & $\mathbf{F}$ & $\%$ & $\mathbf{F}$ & $\%$ & $\mathbf{N}$ & $\%$ & \\
\hline Kejadian Ompalitis & & & & & & & $\mathbf{0 , 0 3 5}$ \\
\hline Ompalitis & 6 & 37,5 & 1 & 6,25 & 7 & 21,88 & \\
\hline Tidak Ompalitis & 10 & 62,5 & 15 & 93,75 & 25 & 78,12 & \\
\hline Total & 16 & 50 & 16 & 50 & 32 & 100 & \\
\hline
\end{tabular}

Tabel 4 menunjukkan bahwa ada penurunan porsentase kejadian ompalitis pada bayi yang dimandikan dan dirawat tali pusatnya sebelum penerapan SOP dan pada bayi yang dimandikan dan dirawat tali pusatnya setelah penerapan SOP yaitu dari 37,5 \% menurun menjadi 6,25\%. Bedasarkan hasil uji statistik menunjukkan bahwa angka pada kolom Asymp.Sig pada uji statistik Mann-Whitney adalah 0,035 yang di bawah 0,05 , maka secara statistik ada perbedaan yang signifikan antara kejadian ompalitis sebelum dan sesudah pelaksanaan standar memandikan dan perawatan tali pusat sesuai SOP.

\section{Pembahasan}

\section{Gambaran karakteritik bayi yang dimandikan dan dirawat tali pusatnya sebelum dan setelah penerapan SOP}

Karakteristik bayi yang dimandikan dan dirawat tali pusatnya terhadap di ruang rawat inap Kebidanan RSUD M dapat dilihat bahwa terdapat $(21,05 \%)$ bayi yang terjadi ompalitis adalah berjenis kelamin laki-laki dan terjadi pada saat dimandikan dan dirawat tali pusatnya sebelum sesuai SOP. Selain disebabkan karena cara dimandikan dan dirawat tali pusatnya sebelum sesuai SOP, juga kerena bayinya berjanis kelamin laki-laki sesuai pendapat Kosim (2010) yang mengatakan bahwa bayi laki-laki 2 kali lipat lebih beresiko dari pada bayi perempuan. Hal ini mungkin karena anatomi alat kelamin laki-laki lebih beresiko mengenai tali pusat bila sedang buang air kecil dan besar. Terdapat (50\%) bayi yang terjadi ompalitis adalah yang lahir dengan SC dan terjadi pada saat dimandikan dan dirawat tali pusatnya sebelum sesuai SOP dan terdapat (100\%) bayi yang terjadi ompalitis adalah yang lahir dengan dukun dan terjadi pada saat dimandikan dan dirawat tali pusatnya setelah sesuai SOP. Selain pengaruh dari cara dimandikan dan perawatan tali pusat, ompalitis juga dapat disebabkan oleh perawatan pada saat bayi lahir dan alat yang digunakan untuk memotong tali pusat, karena bayi lahir dengan tenaga

Indaryani, et.al (Penurunan Ompalitis pada Bayi dengan Prosedur Memandikan....) 
non kesehatan, mungkin alat yang digunakan tidak steril, sehingga dapat menjadi penyebab terjadinya ompalitis.

Hal tersebut sesuai dengan pendapat Rukiyah (2012) yang mengatakan bahwa perawatan tali pusat bayi dimulai setelah plasenta lahir dengan mencelupkan tangan penolong yang masih menggunakan sarung tangan kedalam klorin $0,5 \%$ untuk membersikan darah dan secret, kemudian bilas dengan air DTT dan keringkan. Selanjutnya ikat puntung tali pusat dengan jarak $1 \mathrm{~cm}$ dari diding perut bayi (pusat). Gunakan pengikat atau klem palstik steril dengan simpul mati atau kuncikan penjepitnya serta gunakanlah alat yang steril untuk memotong tali pusat. Ronald (2011) juga menjelaskan bahwa tujuan perawatan tali pusat adalah untuk mencegah terjadinya ompalitis dan tetanus pada bayi. Tetanus bisa disebabkan karena masuknya spora kuman tetanus kedalam tubuh melalui tali pusat, baik dari alat yang tidak steril, pemakaian obat-obatan, maupun bubuk atau daun-daunan yang ditaburkan ketali pusat sehingga dapat mengakibatkan infeksi.

\section{Gambaran pelaksanaan memandikan dan perawatan tali pusat pada bayi sebelum dan setelah penerapan SOP}

Pelaksanaan memandikan dan perawatan tali pusat pada bayi sebelum dan setelah penerapan SOP terjadi beberapa perbedaan pelaksaksanaan langkahlangkah dalam memandikan dan perawatan tali pusat pada bayi, perbedaan tersebut terjadi pada langkah-langkah antara lain : sebelum penerapan SOP, langkah ke-1 dalam SOP (100\%) tidak dilakukan, langkah ke-2 (52\%) tidak dilakukan, langkah ke-14 dalam SOP (24\%) tidak dilakukan sesuai SOP, langkah ke-15 dalam SOP (60\%) tidak dilakukan sesuai SOP, langkah ke-21 dalam SOP (76\%) tidak dilakukan sesuai SOP dan langkah ke-23 dalam SOP (76\%) tidak dilakukan sesuai SOP. Setelah penerapan SOP semua langkah dilakukan sesuai SOP. Langkahlangkah dalam SOP yang tidak digambarkan dalam tabel, semua dilakukan (100\%) sesuai SOP. Langkah ke-1 yaitu perawat tidak mencuci tangan, langkah ke-2 yaitu perawat tidak memakai handscoon, langkah ke-14 yaitu jika ada BAB bayi perawat tidak membersihkan terlebih dahulu sebelum memandikan, langkah ke-15 yaitu pada saat perawat menyabuni bayi tidak sesuai prinsip dari area yang bersih ke yang kotor, langkah ke-21 yaitu pada saat melakukan perawatan tali pusat perawat tidak sesuai prinsip dari pangkal ke ujung tali pusat sesuai SOP, dan langkah ke-23 yaitu perawat memasangkan pakaian bayi sebelum tali pusat dan kulit bayi benar-benar kering, dan tidak melipat popok dibawah tali pusat sehingga popok menutupi area tali pusat.

Selain itu pada saat perawatan tali pusat, perawat juga masih menggunakan kassa alcohol yang tentunya membutuhkan biaya lebih mahal disbanding kasa kering steril, hal ini sejalan dengan pendapat Yunanto, A., Hartoyo, E., \& Budiarti, L. Y. (2016) yang mengatakan bahwa perawatan tali pusat dengan menggunakan alkohol $70 \%$, povidone-iodine $10 \%$ dan kasa kering steril dapat mencegah terjadinya infeksi tali pusat dan tidak berpengaruh terhadap lama lepasnya tali pusat. Namun bila dipandang dari segi ekonomi perawatan tali pusat dengan kasa

Indaryani, et.al (Penurunan Ompalitis pada Bayi dengan Prosedur Memandikan....) 
kering steril dinilai lebih ekonomis dibandingkan perawatan tali pusat dengan menggunakan alkohol $70 \%$ dan povidone-iodine $10 \%$

Pelaksanaan memandikan dan melakukan perawatan tali pusat bayi yang tidak sesuai dengan prinsip standarnya yaitu tidak memakai handscoon, jika ada BAB tidak dibersihkan terlebih dahulu sebelum memandikan, pada saat menyabuni bayi tidak sesuai prinsip dari area yang bersih ke yang kotor, pada saat melakukan perawatan tali pusat tidak sesuai prinsip yaitu dari pangkal ke ujung tali pusat. Tindakan-tindakan yang tidak sesuai standar tersebut dapat menjadi faktor penyebab terjadinya ompalitis. Pendapat tersebut juga didukung oleh Ronald (2011), yang mengatakan bahwa perawatan tali pusat secara umum bertujuan untuk mencegah terjadinya ompalitis dan mempercepat putusnya tali pusat. Ompalitis pada dasarnya dapat dicegah dengan melakukan perawatan tali pusat yang baik dan benar, yaitu sesuai dengan standar dan dengan prinsip perawatan kering dan bersih.

Ronald (2011), juga menguraikan prinsip dari perawatan tali pusat bayi adalah : 1) selalu mencuci tangan sesuai dengan standar dengan sabun sampai bersih sebelum merawat tali pusat bayi, 2) lakukan perawatan tali pusat dengan benar sesuai standar yang telah ditetapkan, 3) membersikan tali pusat sesering mungkin, terutama bila terkena air seni atau kotoran bayi dan jangan lupa tali pusat disabuni setiap setelah bayi dimandikan, 4) tali pusat jangan dibumbuhi dengan ramuan dedaunan, serbuk kopi, parutan kunyit atau bahan lainnya, 5) pada saat merawat tali pusat, perhatikan apakah berbau tajam dan busuk, ada warna kemerahan pada pangkal tali pusat, bengkak, dan keluar cairan nanah atau darah karena semua itu merupakan tanda-tanda ompalitis.

Pelaksanaan memandikan dan melakukan perawatan tali pusat bayi dengan memasangkan pakaian bayi sebelum tali pusat dan kulit bayi benar-benar kering akibatnya tali pusat menjadi lembab dan mudah untuk kerkena infeksi sehingga dapat memperlambat pelepasan tali pusat. Pelaksanaan memandikan dan melakukan perawatan tali pusat bayi dengan tidak melipat popok dibawah tali pusat sehingga popok menutupi area tali pusat dan akibatnya tali pusat bisa terkena kotoran bayi baik dari air kencing maupun BAB yang menyerap melalui popok bayi. Hal ini juga bisa menjadi faktor penyebab terjadinya ompalitis, sesuai dengan JNPK-KR (2007 dalam Rukiyah, 2012) yang mengatakan popok harus dilipat dibawah puntung tali pusat. Selain itu faktor yang juga menjadi penyebab terjadinya ompalitis adalah karena tali pusatnya dibungkus kasa bitadin oleh keluarganya. Penyakit ini disebabkan karena masuknya spora kuman tetanus melalui tali pusat, baik dari alat yang tidak steril, pemakaian obat-obatan, bubuk atau daun-daunan yang ditaburkan ke tali pusat sehingga dapat mengakibatkan infeksi. Perawatan tali pusat adalah tindakan perawatan yang bertujuan merawat tali pusat pada bayi baru lahir agar tetap kering dan mencegah terjadinya infeksi. Perawatan tali pusat yang tidak benar dapat meyebabkan penyakit infeksi yang akan mengakibatkan kematian (Ronald, 2011). Pendapat tersebut juga sejalan dengan JNPK-KR (2007 dalam Rukiyah, 2012) yang menyebutkan pada perawatan tali pusat jangan membungkus tali pusat dan mengoleskan cairan atau bahan apapun, boleh mengoleskan alhokol jika kesterilan pemotongan tali pusat tidak terjamin, tetapi tidak boleh dikompres

Indaryani, et.al (Penurunan Ompalitis pada Bayi dengan Prosedur Memandikan....) 
karena bisa menyebabkan tali pusat lembab dan basah sehingga akan mudah mengakibatkan terjadinya infeksi.

\section{Gambaran kejadian ompalitis pada bayi yang dimandikan dan dirawat tali pusatnya sebelum dan setelah penerapan SOP}

Kejadian ompalitis pada bayi yang dimandikan dan dirawat tali pusatnya sesuai SOP menurun dari $37,5 \%$ menjadi $6,25 \%$, jadi penerapan standar memandikan dan perawatan tali pusat bayi sesuai SOP dan menurun angka kejadian ompalitis sebanyak $31,25 \%$. Bayi yang mendapatkan perlakuan berupa penerapan standar memandikan dan perawatan tali pusat sesuai SOP, perawatan tali pusatnya lebih baik sehingga tali pusat bayi tetap kering dan terjaga kebersihannya, dan tali pusat akan cepat puput serta dapat terhindar dari ompalitis. Pendapat ini dikuatkan oleh Ronal (2011) yang mengatakan bahwa perawatan tali pusat yang baik dan benar akan menimbulkan dampak positif yaitu tali pusat akan puput pada hari ke 57 tanpa komplikasi, sedangkan dampak negatif dari perawatan tali pusat yang tidak benar adalah bayi akan mengalami ompalitis bahkan bisa menjadi tetanus neonatorun yang dapat mengakibatkan kematian. Pernyataan tersebut juga didukung oleh hasil penelitian Damanik, R. (2019) yang menunjukkan adanya hubungan antara perawatan tali pusat dengan kejadian infeksi pada bayi baru lahir (BBL). Diharapkan perawat melakukan tindakan perawatan tali pusat lebih efektif sesuai dengan SOP sehingga terhindar dari angka infeksi pada bayi baru lahir. Penelitian Asiyah, N., Islami, I., \& Mustagfiroh, L. (2017) juga diperoleh pada kelompok perawatan tali pusat terbuka, pelepasan tali pusat lebih cepat dengan nilai significancy 0.022 . Karena pvalue $<0.05$ maka dapat disimpulkan bahwa ada perbedaan bermakna lama pelepasan tali pusat antara perawatan tali pusat terbuka dengan perawatan tali pusat tertutup.

Pada penelitian ini, SOP yang diterapkan berisikan tentang langkah-langkah cara memandikan dan perawatan tali pusat bayi agar tali pusat tetap kering dan terjaga kebersihannya dan terhindar dari ompalitis sehingga tujuan dari perawatan tali pusat dapat tercapai yaitu seperti yang dikatakan oleh Ronal (2012) bahwa tujuan perawatan tali pusat adalah untuk mencegah terjadinya ompalitis dan tetanus pada bayi yang dapat disebabkan karena masuknya spora kuman tetanus kedalam tubuh melalui tali pusat, baik dari alat yang tidak steril, pemakaian obat-obatan, maupun bubuk atau daun-daunan yang ditaburkan ketali pusat sehingga dapat mengakibatkan infeksi. Selain itu ompalitis juga terjadi pada bayi yang via IGD yang lahir dengan tenaga non kesehatan yang mungkin menggunakan peralatan yang tidak steril. Ronal (2012) mengatakan bahwa ompalitis bisa disebabkan karena masuknya kuman kedalam tubuh melalui tali pusat, baik dari alat yang tidak steril pada saat pemotongan, pemakaian obat-obatan, maupun bubuk atau daundaunan yang ditaburkan ketali pusat sehingga dapat mengakibatkan infeksi.

Ronald (2012) mengatakan pencegahan pada ompalitis dapat dilakukan dengan cara antara lain : 1) merawat tali pusat dengan teratur dan sesuai standar, 2)

Indaryani, et.al (Penurunan Ompalitis pada Bayi dengan Prosedur Memandikan....) 
cuci tangan sebelum dan sesudah merawat bayi, 3) bila tali pusat kotor cuci tali pusat dengan air bersih dan jangan merendam tali pusat baik pada saat perawatan tali maupun saat memandikan bayi, 4) biarkan tali pusat mengering, lalu tutup longgar dengan kasa steril dan kering, 5) lipat popok bibawah tali pusat. Perawatan tali pusat yang dilakukan dengan benar, sesuai dengan prosedur dan harus memperhatikan kebersihan. Tujuan perawatan tali pusat pada bayi adalah agar tali pusat tetap dalam keadaan sehat dan tidak ditemukan tanda-tanda infeksi. Dampak positif dari perawatan tali pusat dengan prinsip kering dan bersih adalah bayi akan sehat dengan kondisi tali pusat bersih dan tidak terjadi infeksi serta tali pusat pupus lebih cepat, yaitu antara hari ke 7-10 tanpa ada komplikasi (Lestari, 2013) dan metode perawatan tali pusat secara terbuka memiliki rata-rata pelepasan tali pusat $>7$ hari (60\%) dan 5 - 7 hari (40\%) Yuliana, F., Mahpolah, M., \& Rosyana, D. (2017).

Ronald (2012) juga mengatakan bahwa tujuan perawatan tali pusat adalah untuk mencegah terjadinya ompalitis dan tetanus pada bayi. Perawatan tali pusat sangat penting dilakukan untuk mencegah infeksi. Tujuan perawatan tali pusat untuk mencegah terjadinya penyakit tetanus pada bayi baru lahir, agar tali pusat tetap bersih, kuman- kuman tidak masuk sehingga tidak terjadi infeksi pada tali pusat bayi. Penyakit tetanus ini disebabkan oleh clostridium tetani yaitu kuman yang mengeluarkan toksin (racun), yang masuk melalui luka tali pusat, karena perawatan atau tindakan yang kurang bersih (Saifuddin, 2014).

\section{Perbedaan kejadian ompalitis pada bayi yang dimandikan dan dirawat tali pusatnya sebelum dan setelah penerapan SOP}

Berdasarkan hasil analisis data, didapatkan bahwa hipotesis yang diterima adalah kelompok yang diberi perlakuan berupa penerapan standar memandikan dan perawatan tali pusat sesuai SOP lebih sedikit yang terjadi ompalitis yaitu 6,25\% dibanding dengan kelompok sebelum penerapan standar memandikan dan perawatan tali pusat sesuai SOP yaitu sebanyak 37,5\%. Secara statistik hasil analisis data didapatkan $\mathrm{p}$ value $=0,035$ yang berarti ada pengaruh yang signifikan antara kejadian ompalitis pada bayi setelah dimandikan dan dirawat tali pusatnya sesuai SOP dengan yang sebelum sesuai SOP.

Ompalitis merupakan bagian infeksi nasokomial yang terjadi di rumah sakit dan infeksi nosokomial merupakan salah satu indikator mutu pelayanan asuhan keperawatan untuk mengukur tingkat efisiensi rumah sakit. Berdasarkan standar pelayanan minimal rumah sakit Depkes RI (2015), kejadian infeksi nosokomial adalah $\leq 1,5 \%$. Dalam penelitian ini didapatkan kejadian infeksi nosokomial sebelum penerapan standar memandikan dan perawatan tali pusat sesuai SOP adalah $37,5 \%$ dan setelah penerapan standar memandikan dan perawatan tali pusat sesuai SOP adalah yaitu $6,25 \%$. Hasil penelitian ini secara statistik ada perbedaan yang signifikan yang artiny efektia sebagai upaya menurunkan kejadian infeksi nosomomial, tetapi hasil penelitian ini masih jauh diatas standar Kemenkes RI (2015) yang menetapkan bahwa kejadian infeksi nosokomial $\leq 1,5 \%$. Hal ini dikarenakan, faktor yang dapat mempengaruhi kejadian ompalitis bukan hanya

Indaryani, et.al (Penurunan Ompalitis pada Bayi dengan Prosedur Memandikan....) 
pelaksanaan memandikan dan perawatan tali pusat bayi tetapai masih banyak faktor yang lain yang dapat mempengaruhi terjadinya ompalitis seperti air yang digunakan untuk memandikan adalah air dari Perusahan Air Minum (PAM) yang kebersihan dan kebebasannya dari bakteri tidak diketahui, seperti hasil dari wawancara peneliti pada saat servei awal, wakil kepala ruang kebidanan mengatakan bahwa kejadian ompalitis meningkat pada musim hujan.

Faktor pengetahuan ibu juga dapat mempengaruhi kejian infeksi tali pusat pada bayi seperti hasil penelitian Wulandari, S., \& Kusumawati, L. S. (2020) yang mengatakan bahwa Hasil penelitian diinterpretasikan bahwa sebelum diberi pelatihan sebagian besar responden $20(61 \%)$ cukup terampil melakukan perawatan tali pusat, sesudah diberi pelatihan sebagian besar responden $22(67 \%)$ terampil melakukan perawatan tali pusat. Kemudian dengan uji Wilcoxon Signed Ranks Test dan taraf signifikansi (Î̀) 0,05 menunjukkan nilai p 0,000. Keputusannya jika $\mathrm{p}<0,05$ adalah $\mathrm{H}_{0}$ ditolak dan $\mathrm{H}_{1}$ diterima, artinya, ada Pengaruh Pelatihan Perawatan Tali Pusat Terhadap Keterampilan Ibu Dalam Perawatan Tali Pusat Pada ibu nifas di masa pandemic. Kesimpulan penelitian ini adalah $\mathrm{H}_{0}$ ditolak dan $\mathrm{H}_{1}$ diterima, artinya, ada Pengaruh Pelatihan Perawatan Tali Pusat Terhadap Keterampilan Ibu Dalam Perawatan Tali Pusat Pada Ibu Nifas Di masa pandemic.

Selain faktor air dan pengetahuan, faktor lingkungan juga kemungkinan bisa menjadi penyebab terjadinya ompalitis seperti ruangan yang banyak pengunjung terutama pada malam hari, banyaknya barang-barang bawaan pasien diruang perawatan tempat bayi dirawat. Pakaian yang dipakai oleh keluarga yang bersentuhan langsung dengan bayi terutama ibu bayi. Selain melakukan evaluasi terhadap hal-hal yang memungkinkan dapat menyebabkan ompalitis, manajemen juga mengevaluasi fungsi-fungsi manajemen yang terkait dengan pelaksanaan pelaksanaan standar, agar pelaksanaan standar seperti SOP dapat berjalan sesuai dengan tujuan yang diharapkan seperti SOP memandikan dan perawatan tali pusat yang dapat menurunkan angka kejadian ompalitis jika dilaksanakan sesuai standar. Hal ini sesuai dengan pendapat Kurniadi (2013) yang mengatakan adapun tujuan dari ditetapkannya pedoman kerja perawat adalah agar perawat bekerja sesuai dengan standar yang telah ditetapkan dan kinerja perawat sesuai dengan hasil yang diharapkan sehingga mutu pelayanan keperawatan dapat mencapai standar yang telah ditetapkan. Oleh karena itu mencapai tujuan tersebut fungsi manajemen harus berjalan dengan baik mulai dari fungsi perencanaan sampai dengan pengendalian.

Fungsi perencanaan merupakan tahap paling awal dari proses manajemen, dalam hal ini fungsi perencanaan diperlukan untuk tersedianya standar dan adanya kebijakan tentang standar tersebut, termasuk SOP. Menurut Kurniadi (2013) salah satu yang ada dalam fungsi perencanaan adalah adanya standar kerja dan kebijakan pimpinan intsitusi termasuk tentang standar tersebut. Kurniadi juga mengatakan SOP merupakan pedoman kerja tetap dan sub spesifik bagi profesi tertentu misalnya perawat. SOP berisi pedoman kerja satu tindakan tertentu dimana standar itu berlaku nasional dan internasional sehingga organisasi mengikuti yang sedang berlaku saat tertentu seperti SOP memandikan dan perawatan tali pusat bayi. Fungsi pengorganisasian juga menjelaskan tentang pola struktur organisasi dan

Indaryani, et.al (Penurunan Ompalitis pada Bayi dengan Prosedur Memandikan....) 
penataan kegiatan organisasi seperti yang di jelaskan oleh Simamora (2012) bahwa aspek penting dalam pengorganisasian meliputi pola struktur organisasi dan penataan kegiatan organisaansi dan Kurniadi (2013) mengatakan bahwa dalam fungsi pengorganisasian salah satu fungsi kepala ruangan adalah harus menjelaskan bagaimana melaksanakan asuhan keperawatan sesuai Standar Asuhan Keperawatan (SAK) dan Standard Operatinal Prosedur (SOP) sesuai dengan kriteria pedoman kerja.

Kurniadi (2013) menjelaskan standar yang memenuhi kriteria pedoman kerja yaitu antara lain adalah a) Menciptakan media bagi staf perawat untuk bertanya, menjadi arahan dan konsultasi. b) Jenis petunjuk kerja berisi kebijakan, prosedur, standar kinerja dan job description. c) Ada program pelatihan staf baik periodik atau temporer yang didesain agar tidak mengganggu irama kerja yang sudah baik. d) Memiliki supervisor yang kompeten dibidangnya. Ada kemauan untuk menerapkan standar kerja yang benar. f) Ada contoh dari pimpinan dalam penerapan standar kerja yang benar. g) Memakai tehnik analisa operasional sehingga mudah ditirukan semua orang. h) Menggunakan tehnik manajemen by objektif agar tujuan benar-benar terfokus. i) Ada perhatian dari semua lini pimpinan. j) Semua anggota terorganisir dengan baik terutama dalam melaksanakan pelayanan keperawatan secara langsung ke pasien. Semua perencanaan pedoman kerja diupayakan menguntungkan semua staf, dalam arti tidak menambah beban tetapi nambah kepuasan dan kesejahteraan sehingga standar dapat dilaksanakan dan dilakukan evaluasi.

Fungsi pengendalian dan pengawasan salah satunya adalah bertujuan untuk melakukan evaluasi terhadap pelaksanaan standar. Evaluasi suatu standar adalah bagian dari fungsi manajmen terutama manajemen keperawatan khususnya fungsi pengawasan dan pengendalian. Seperti menurut Suarli dan Bactiar (2010). mengatakan pengawasan adalah suatu proses untuk mengetahui apakah pelaksanaan kegiatan/pekerjaan sesuai dengan rencana, pedoman, ketentuan, kebijakan, tujuan, sasaran yang sudah ditentukan sebelumnya. Maksud dan tujuan dari pengawasan adalah untuk mencegah atau memperbaiki kesalahan, penyimpangan, dan ketidaksesuaian yang dapat mengakibatkan tujuan/sasaran organisasi tidak tercapai dengan baik, karena pelaksanaan pekerjaan/kegiatan tidak efisien dan tidak efektif.

Suarli dan Bactiar(2010) juga menjelaskan kegunaan pengawasan antara lain adalah : 1) Mencegah penyelewengan, penyalahgunaan wewenang, pemborosan, dan kerugian organisasi. 2) Meningkatkan rasa tanggung jawab pelaksana pekerjaan. 3) Memperbaiki kesalahan penyelewengan dan penyalahgunuaan wewenang yang telah terjadi. 4) Mendidik setiap orang agar bekerja sesuai dengan prosedur dan peraturan. Menurut Gillies (1996 dalam Sitorus, 2011), macam dan tipe pengawasan terbagi menjadi 3 yaitu : 1) Jika dilihat dari kedudukan unit pengawasan terdiri atas pengawasan dari dalam (internal control), dan pengawasan dari luar (eksternal control). 2) Jika dilihat dari sasarannya terdiri atas pengawasan preventif (pencegahan) yang dilakukan sebelum pelaksanaan dan pengawasan represif pada saat atau sesudah pelaksanaan.

Indaryani, et.al (Penurunan Ompalitis pada Bayi dengan Prosedur Memandikan....) 
Menurut Stevens (1985 dalam Sitorus, 2011) yang paling penting dalam pelaksanaan fungsi manajemen keperawatan adalah standar pengawasan mutu asuhan keperawatan terdiri dari standar struktur, proses dan outcome. Standar dapat berupa internal dan eksternal. Standar internal dikembangkan oleh pimpinan perawat, manajer, dan staf dalam organisasi, standar dapat berupa standar ketenagaan dalam organisasi atau kebijakan departemen, prosedur-prosedur keperawatan, dan struktur organisasi. Standar eksternal berasal dari berbagai sumber yaitu pemerintah, organisasi profesi, institusi, unit perawatan, dan individu. Standar yang sudah dilaksanakan juga harus dievaluasi untuk mengidentifikasi kekuatan dan kelemahan dari standar. Jika ada hal-hal yang tidak dapat dilaksanakan atau tidak sesuai dengan tujuan standar, organisasi harus dapat membuat perencanaan untuk tindakan koreksi, yang merupakan salah satu fungsi pengendalian mutu keperawatan.

Menurut Kurniadi (2013) program pengendalian mutu mengikuti pendekatan sistem yang dimulai dari unit ruang keperawatan dimana perawat sebagai provider akan menerapkan asuhan keperawatan kepada pasien. Setiap unit memiliki standar kerja sendiri, akan tetapi dalam pelaksanaan asuhan keperawatan tetap menerapkan standar yang telah disusun dalam bentuk SOP yang sudah ditetapkan. Bila setiap unit atau devisi sudah menerapkan SOP, maka akan dapat dijamin bahwa mutu asuhan keperawatan dapat berjalan dengan profesional dan pelayanan juga dapat bermutu. Fungsi pengendalian dalam manajemen keperawatan salah satunya adalah pengendalian mutu yang dapat dilakukan dengan cara menetapkan dan memperbaiki pedomen kerja bagi tenaga keperawatan. SOP merupakan pedoman kerja tetap dan sub spesifik bagi profesi tertentu misalnya perawat atau dokter. SOP berisi pedoman kerja satu tindakan tertentu dimana standar itu berlaku nasional dan internasional sehingga pihak organisasi mengikuti apa yang sedang berlaku saat tertentu agar tujuan diterapkannya SOP dapat tercapai.

Menurut Kurniadi (2013) tujuan dari SOP pelayanan keperawatan adalah untuk mengarahkan dan membimbing perawat dalam memberikan layanan yang efektif dan efesien sehingga dapat menurunkan biaya yang tidak perlu, menurunkan angka Length Of Stay (LOS) dan melindungi perawat dari kejadian kelalaian yang tidak disengaja dan tujuan dari standar keperawatan adalah untuk meningkatkan mutu asuhan keperawatan, mengurangi biaya asuhan keperawatan, melindungi perawat dari kelalaian dalam melaksanakan tugas dan melindungi pasien dari tindakan yang tidak terapeutik. Ruang lingkup SOP adalah materi mengandung prosedur kerja/tahapan kerja satu tindakan profesi tertentu yang harus ditentukan/ditetapkan oleh sub unit organisasi walaupun berlakunya nasional atau internasional serta digunakan hanya untuk unit organisasi pembuat. Materi bisa berubah bila persatuan profesi menemukan metode baru yang lebih profesional. Berlaku untuk unit organisasi sendiri. Prosedur kerja mengandung tindakan profesional seorang ahli dan alur pemecahan masalahnya. Sifatnya harus ada demi menjamin mutu organisasi profesi. Misalnya SOP mencuci tangan, SOP memandikan dan merawat tali pusat bayi.

Indaryani, et.al (Penurunan Ompalitis pada Bayi dengan Prosedur Memandikan....) 


\section{SIMPULAN}

Terdapatnya perbedaan yang signifikan kejadian ompalitis pada bayi yang dimandikan dan dirawat tali pusat sebelum dan setelah penerapan SOP dan terdapatnya penurunan kejadian ompalitis pada bayi yang dimandikan dan dirawat tali pusatnya setelah penerapan SOP.

\section{DAFTAR PUSTAKA}

Asiyah, N., Islami, I., \& Mustagfiroh, L. (2017). Perawatan Tali Pusat Terbuka Sebagai Upaya Mempercepat Pelepasan Tali Pusat. Indonesia Jurnal Kebidanan, 1(1), 29-36.

Damanik, R. (2019). Hubungan Perawatan Tali Pusat dengan Kejadian Infeksi pada Bayi Baru Lahir di RSUD Dr. Pirngadi Medan 2019. Jurnal Keperawatan Priority, 2(2), 51-60.

Dharma, KK. (2011). Metodologi Penelitian Keperawatan : Panduan melaksanakan dan menerapkan hasil penelitian. Jakarta : Tim

Depkes RI. (2015). Asuhan persalinan normal. Jakarta: Depkes RI.

Depkes (2016). Data infeksi tali pusat pada bayi. Medan : Depkes.

Erenel, AS, Vural, G, Efe, SY, Ozkan, S, Ozgen, S, Erenuglu, R. (2010). Comparison of Olive Oil and Dry-Clean Keeping Methods in Umbilical Cord Care Microbiological. Matern Child Health J. (diakses pada 26 Februari 2014)

Hastomo \& Sabri. (2010). Statistik Kesehatan ed.5. Jakarta : Bina Aksara

Hidayat, AA. (2008). Pengantar Ilmu Kesehatan Anak. Jakarta : Salemba Medika Kosim, M.S, dkk. (2010). Buku Ajar Neonatologi. Jakarta : IDAI

Kurniadi, A. (2013). Manajemen Keperawatan dan Prospektifnya : Teori Konsep dan Aplikasi. Jakarta : FKUI.

Lestari, (2013) . Panduan belajar: keperawatan ibu-bayi baru lahir ed.3.

Jakarta : EGC.

Notoadmodjo, $\quad$ S. (2010). Metodologi penelitian kesehatan. Jakarta : Rineka Cipta

Nursalam. (2011). Konsep Dan penerapan metodologi Penelitian keperawatan. Jakarta : Salemba Medika. Perwitasari, N. (2007). Tingkat Pengetahuan Ibu Nifas Tentang Perawatan Tali Pusat di Puskesmas Margangsan. Yokyakarta : Respati.

Purnamasari, L. (2016). Perawatan Topikal Tali Pusat untuk Mencegah Infeksi pada Bayi Baru Lahir. Cermin Dunia Kedokteran, 43(5), 395-398.

Ronald, H.S. (2011). Pedoman perawatan balita. Bandung : Nuansa Aulia.

Rukiyah, AY. (2012). Asuhan Bayi, Bayi dan Anak. Jakarta : TIM

Saipuddin. (2014). Pelayanan kesehatan ibu dan bayi. Jakarta :EGC

Indaryani, et.al (Penurunan Ompalitis pada Bayi dengan Prosedur Memandikan....) 
Saryono \& Anggraeni, MD. (2013). Metodologi Penelitian Kualitatif dan Kuantitatif dalam bidang kesehatan. Yogyakarta : Nuha Medika.

Sastoasmoro, S. (2011). Dasar-dasar Metodelogi Penelitian Klinis, Ed.4. Jakarta : CV.Sagung Seto.

Simamora, R. (2012). Buku Ajar Manajemen Keperawatan. Jakarta :EGC

Sitorus, R \& Panjaitan, R. (2011). Manajemen keperawatan: Manajemen keperawatan di ruang rawat inap. Jakarta : CV.Sagung Seto.

Sodikin (2015). Buku Saku Perawatan Tali Pusat. Jakarta : EGC.

Sogiyono. (2013). Metode Penelitian Kuantitatif, Kualitatif dan Kombinasi, (Mixed Method). Bandung: Alfabeta

Sopiyaduin, D. (2011). Statistik Untuk Kedokteran dan Kesehatan Deskriptif, Bivariat, dan Multivariat dilengkapi Aplikasi dengan Menggunakan SPSS. Jakarta Salemba Medika.

Suarli \& Bacthiar. (2010). Manajemen Keperawatan dengan Aplikasi Pendekatan Praktis. Jakarta : Erlangga

Wulandari, S., \& Kusumawati, L. S. (2020). Pengaruh Pelatihan Perawatan Tali Pusat Terhadap Keterampilan Ibu Dalam Perawatan Tali Pusat Pada Ibu Nifas Di Masa Pandemi. Jurnal Bidan Pintar, 1(2), 150-160.

Yefri R, Mayetti dan Machmud. (2010). Kolonisasi kuman dan kejadian omfalitis pada tiga regimen perawatan tali pusat pada bayi baru lahir. Sari pediatri, Vol. 11 No.5.

Yuliana, F., Mahpolah, M., \& Rosyana, D. (2017). Metode Perawatan Tali Pusat Terbuka Pada Bayi Di Ruang Bayi Rsud. Ulin Banjarmasin. Dinamika Kesehatan: Jurnal Kebidanan Dan Keperawatan, 8(1), 19-24.

Yunanto, A., Hartoyo, E., \& Budiarti, L. Y. (2016). Peran Alkohol 70\%, PovidonIodine 10\% dan Kasa Kering Steril dalam Pencegahan Infeksi pada Perawatan Tali Pusat. Sari Pediatri, 7(2), 58-62.

Yuspita (2017). Sepsis pada neonatus (sepsis neonatal). Sari Pediatri, Vol. 2,

No. 2 : 96-102.

Indaryani, et.al (Penurunan Ompalitis pada Bayi dengan Prosedur Memandikan....) 